\title{
EGFR NM_005228.3:c.2235_2246del12
}

National Cancer Institute

\section{Source}

National Cancer Institute. EGFR NM 005228.3:C.2235 2246de/12. NCI Thesaurus. Code C98543.

A deletion of 12 nucleotides from the coding sequence of the EGFR gene from position 2235 through 2246. 